\title{
悪性腫瘍との鑑別が困難であった耳下腺膿瘍
}

\author{
田中 和成 ${ }^{1)} \cdot$ 北嶋 和智2) - 井上 秀蔵 2$) \cdot$ 駒田 一朗 33

\section{Differential Diagnosis of Parotid Abscess from Malignant Tumors}

\author{
Kazunari Tanaka \\ (Kusatsu Central Hospital) \\ Kazutomo Kitajima and Shuzo Inoue \\ (Shiga University of Medical Science) \\ Ichiro Komada \\ (Koga Public Hospital)
}

\begin{abstract}
We report here 2 cases of parotid abscesses which were difficult to distinguish from malignant tumors.

Case 1. A 5-y.o.-male had a sudden right parotid swelling without any particular inducement. There were no signs of inflammation based on clinical symptoms or laboratory data. A malignant tumor was suspected based on indications by both the cold image on the Tc scintigraph and the hot image on the Ga scintigraph. Surgical observation recalled that there was an abscess formed in the parotid gland, and its wall adhered to the facial nerve.

Case 2. A 70-y.o.-male with diabetes mellitus had been treated with oral medicines. He had left parotid swelling with pyrexia and pain and had left facial nerve paralysis as well. Since there was the possibility of a malignant tumor because of the facial nerve paralysis, we performed a biopsy through the ulcer. However, there were no neoplastic changes, only inflammation. Surgical observation showed that the parotid gland was scarred and no tumor tissue was observed. The adhesions to the facial nerve were friable and not hard.

According to the pathologic diagnosis, both cases had chronic parotiditis with abscess formation. A conclusive observation which distinguishes a benign tumor from a malignant tumor is not available for inflammation of parotid gland. In case 1 , there were no signs of inflammation, and the hot image on the Ga scintigraph were suggestive of a malignant process. In case 2 , the existence of the facial nerve paralysis made it difficult to distinguish from a malignant tumor.
\end{abstract}

Key words : parotid abscess, chronic parotiditis, Ga scintigraph, facial nerve paralysis

はじめに

近年化膿性耳下腺炎, 耳下腺膿瘍は比較的稀な疾患と なっている.これは抗生剤の発達によるところが大きく， 治療が容易になり, 合併症も特に問題にされることは少
ない，しかし不適切な抗生剤の投与は炎症を隠蔽し，慢 性化や膿瘍形成をさたすことがある、また，糖尿病等の 全身疾患の存在が, 炎症を重症化, 遷延化させることも ある、またこれらに関連して, 耳下腺の炎症性疾患の中

3）公立甲賀病院耳鼻咽喉科 
には悪性疾患との鑑別が問題となることもある11.今回 我々は，悪性腫瘍との鑑別が困難であった耳下腺膿瘍を 経験した。 2 症例を提示し，その臨床像について問題点 を含め考察を加光報告する。

\section{症例}

\section{【症例 $1 】$}

患者：5 歳, 男児.

主訴：右耳下部腫脹,

家族歴 : 特記事項なし。

既往歷：アレルギー性鼻炎，アトピー性皮膚炎。

現病歷：1990年 2 月，特に誘因なく右耳下部が腫脹し 急激に増大した。近医耳鼻咽喉科で同部位の腫瘤を指摘 され，同年 3 月 1 日滋賀医科大学耳鼻咽㮢科を紹介受 診した。

初診時所見（図 1 ）：右耳下部に $30 \times 40 \mathrm{~mm}$ の弾性硬, 表面平滑, 境界注济明膫, 可動性概ね良好な腫瘤を認め た。発熱, 局所の熱感, 発赤, 圧痛, 自発痛はなく, ま た耳下部の圧迫にてもステノン管からの膿汁の排出はな かった。両側頸部に 5 10 mm 程度のリンパ節を多数触 知した.

検查所見：血液検査では，アミラーゼが若干高值であ る以外は, 白血球の増加, 分画の異常もなく, CRP は 陰性で, 血沈の促進もなかった。

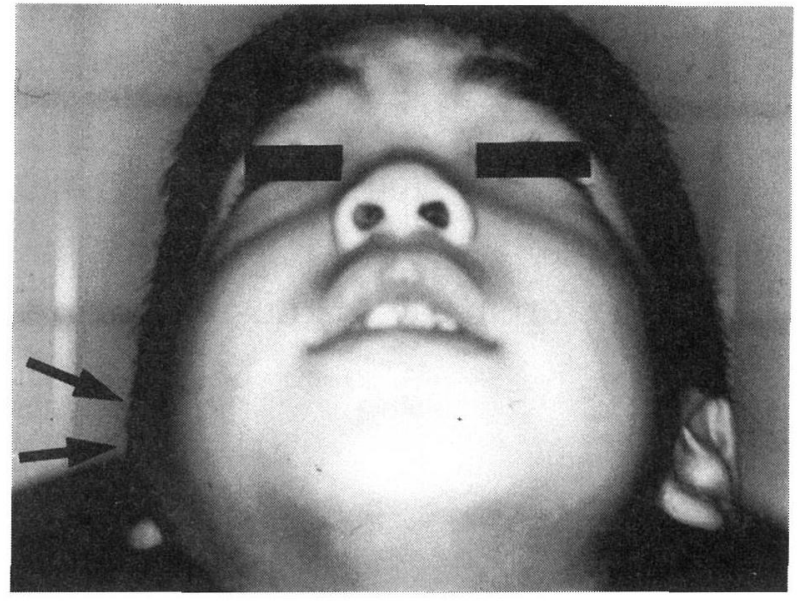

図 1 局所所見(症例 1$)$

右耳下部の腫瘤(矢印) は $30 \times 40 \mathrm{~mm}$ の弾性硬, 表面平 滑, 境界注湆明膫, 可動性概惝良好で, 熱感, 発赤, 圧 痛，自発痛はなかった。

超音波所見：エコーでは数個の囊胞形成があった．

$\mathrm{RI}$ シンチ所見(図 2)：Tc シンチで欠損像を，Gaシ ンチで陽性像を示し，悪性腫瘍，特にリンパ腫を疑った。 CT 所見（図 3)：周囲がやや造影効果を受ける lowdensity area として描出された。

耳下腺造影所見(図 4): 造影剤(リピオドール®)は円

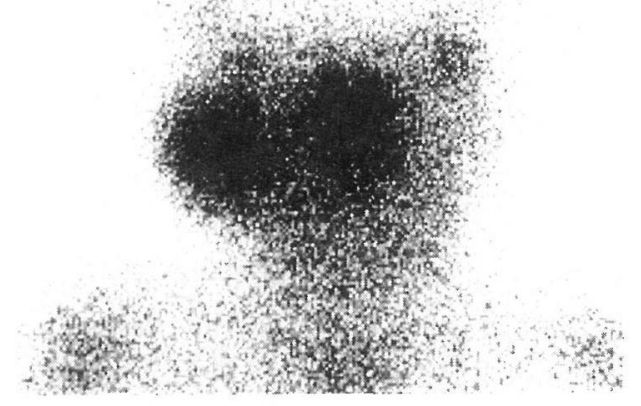

$67 \mathrm{G}$ a

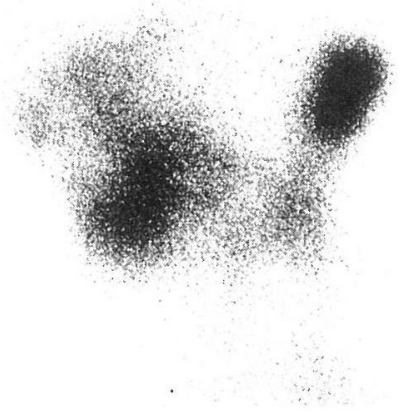

$99 \mathrm{~m}_{\mathrm{CO}}$

图 2 RI シンチ(症例 1)

Tc シンチは欠損像を示し, 同部位に一致して Ga シンチでは陽性像を示した。 


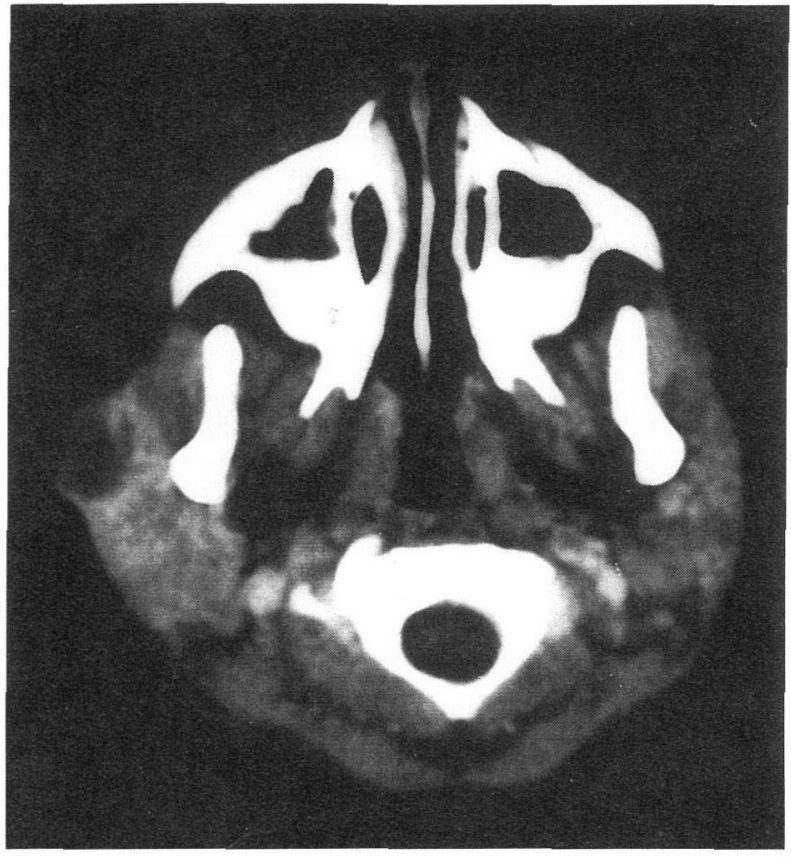

図 3 CT 所見 (症例 1)

耳下腺内に襄胞状の low-density area があり午の塥囲は 造影効果を受けている.
形の囊胞様腔内にそのほとんどが入り, 貯留囊胞の可能 性が大きくなった。

経過：ジアログラム，エコーでの所見より囊胞を疑い つつも，急激な増大，炎症所見の之しさ，Gaシンチで の陽性像より悪性腫瘍を除外し得ず，1990年 3 月19日確 定診断を兼ね手術を行った。

手術所見（図 5 ）：耳下腺の腫瘤は波動を触れた。壁は 周囲組織，特に顔面神経と強く癒着していたが，腫瘍性 の癒着よりもむしろ炎症性の癒着であった，壁を術中迅 速病理検査に出したところ腫瘍性変化はなく炎症所見の みであった，内容は黄白色の膿汁であった。明確な被膜 はなく，囊胞よりもむしろ数力所の膿瘍形成があった。 膿瘍を開放しドレナージをつけ，手術を終了した。

病理組織所見 : 組織標本では腫瘍性変化は認められず, 慢性耳下腺炎の診断を得た。結核の所見はなかった。

転帰：ドレーンチューブより抗生剂の注入を行った。 ドレーンチューブは術後 4 日で抜去し，ガーゼタンポン にて創の癒合を待った．局所の経過は順調であり，耳前 部皮膚に若干の瘢痕形成を残すものの再発の徵候はない.

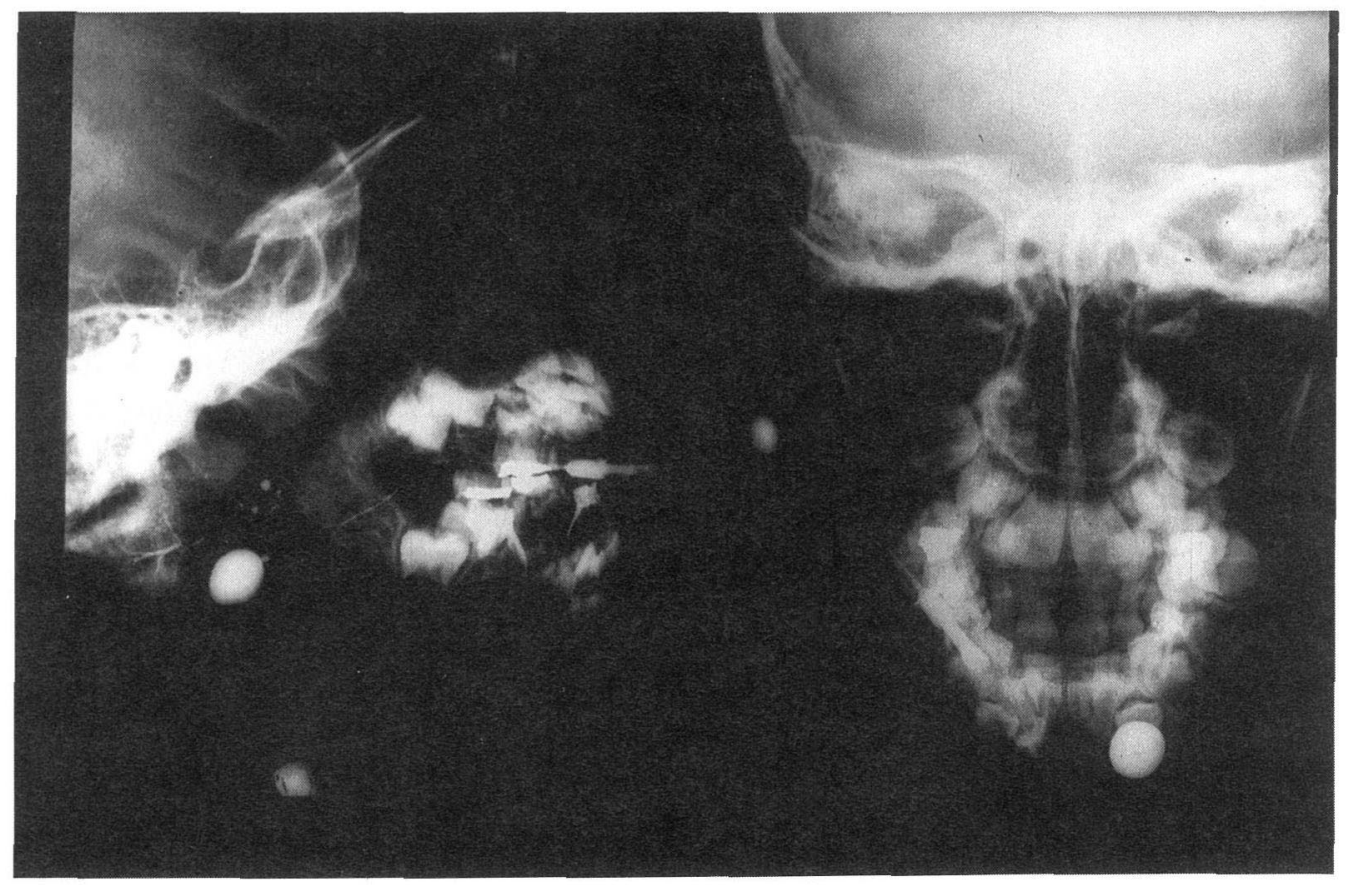

図 4 耳下腺造影所見(症例 1 )

造影剂( リピオドール®) は円形の囊胞様腔内にそのほとんどが入り，貯留襄胞の可能性が大きい。 


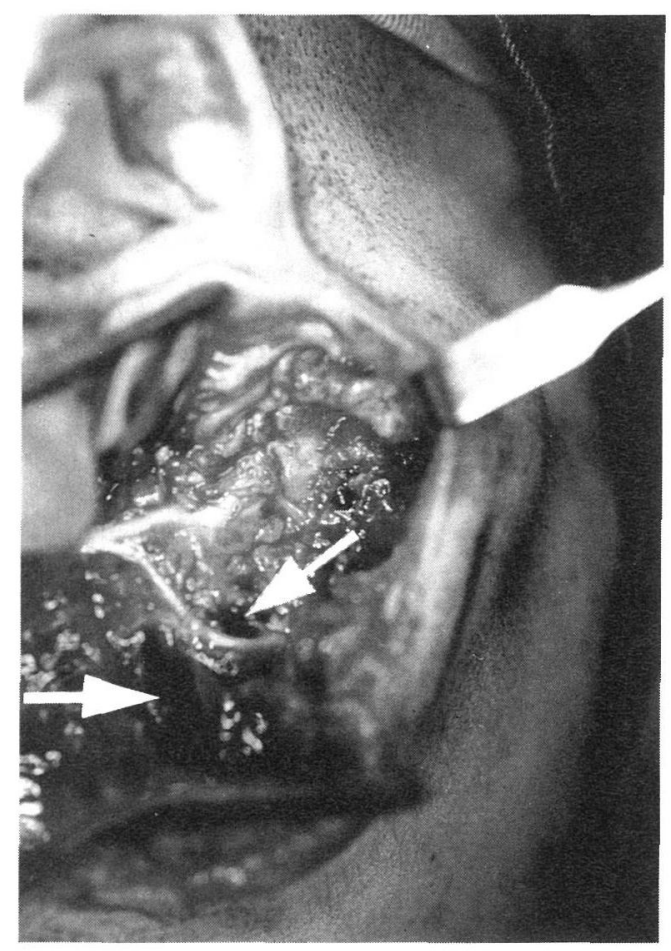

図 5 手術所見(症例 1)

耳下腺の腫瘤は波動を触れた。壁は周团組織と炎症性の 瘉着があった。内容は黄白色の膿汁であった。明確な被 膜はなく数力所に膿瘍形成があった． 矢印が膿瘍腔.

\section{【症例 2】}

患者：70歳，男性.

主訴：左耳下部腫脹, 顔面神経麻痺.

家族歴：特記事項なし.

既往歴：糖尿病; 内服治療中.

現病歴：1990年 5 月, 発熱, 自発痛を伴ら左耳下部腫 脹が出現した. 2 日後左顔面神経麻痺も出現した. 同年 5 月10日滋賀医科大学耳鼻咽喉科を紹介受診した.

初診時所見(図 6)：左耳下部に $70 \times 80 \mathrm{~mm}$ の弾性硬, 表面ほぼ平滑, 境界不明瞭, 可動性不良な腫瘤を認めた。 2 カ所で自潰があった。、ステノン管からの膿汁の排出は なかった。

検査所見：白血球の増加, CRP は陽性, 血沈の促進 があった、また空腹時の高血糖があった。

RI シンチ所見：Ga シンチで陽性像を示した.

CT 所見（図 7): 囊胞状の low-density area と, その 周团が強く造影される腫瘤があり, 境界は不明瞭であっ

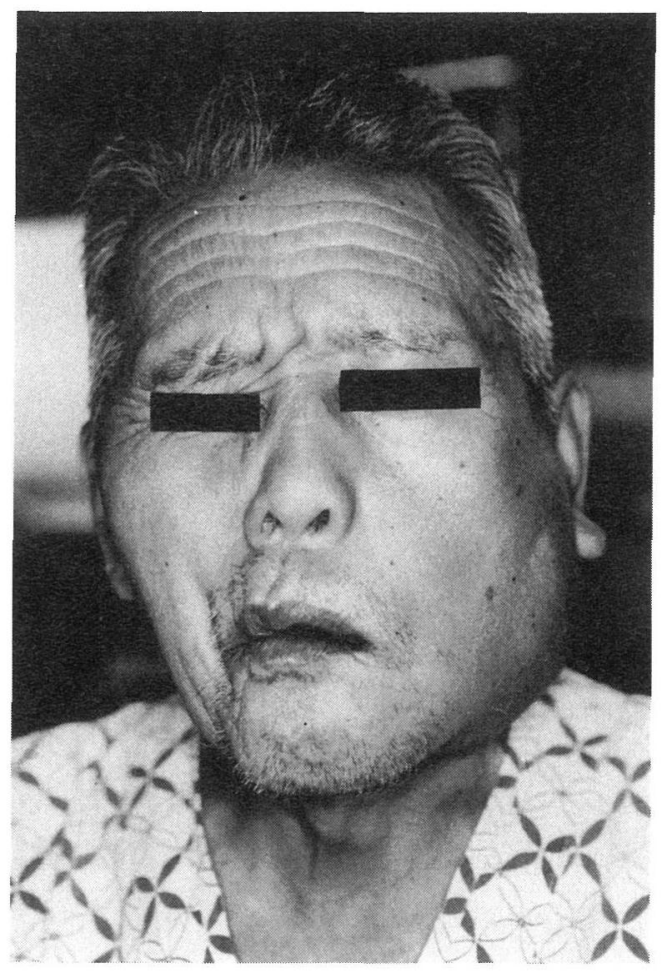

図 6 局所所見(症例 2)

左耳下部の腫瘤は $70 \times 80 \mathrm{~mm}$ の弾性硬, 表面ほぼ平滑, 境界不明瞭, 可動性不良で， 2 力所で自潰があった。同 側の顔面神経麻痺があった。

た。

経過 : 糖尿病は近医内科にて内服治療中であったが, コントロールは不良であり，入院後はインスリンにて厳 密にコントロールした. 顔面神経麻痺の存在より悪性腫 瘍の可能性を考慮し，数回にわたり自潰部開放創より生 検を行ったが，炎症所見のみで腫瘍性変化は認められな かった.

1990年 6 月20日確定䛦断を兼ね手術を行った。

手術所見（図 8)：耳下腺浅葉は症痕化して扣り明確な 腫瘍はなく，数力所を術中迅速生検したが炎症所見のみ で腫瘍性の変化は認められなかった。耳下腺の浅葉切除 を行った，顔面神経との瘉着は強くなかった．創を閉鎖 し手術を終了した。

病理組織所見：組織標本では腫瘍性变化は認められな かった。

転帰：インスリンにより血糖はコントロールされ，創 は良好に治癒した，顔面神経麻痺に変化はなかった。 


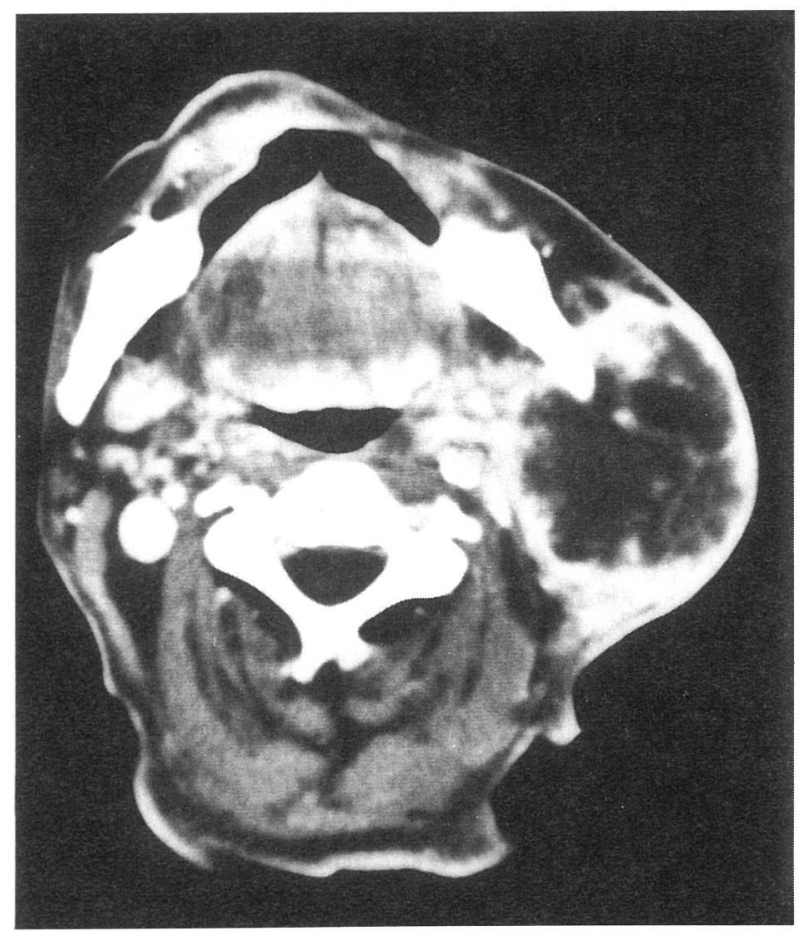

図 7 CT 所見(症例 2)

耳下腺には輫胞状の low-density area があり, 周囲は強 く造影され，境界は不明瞭であった。

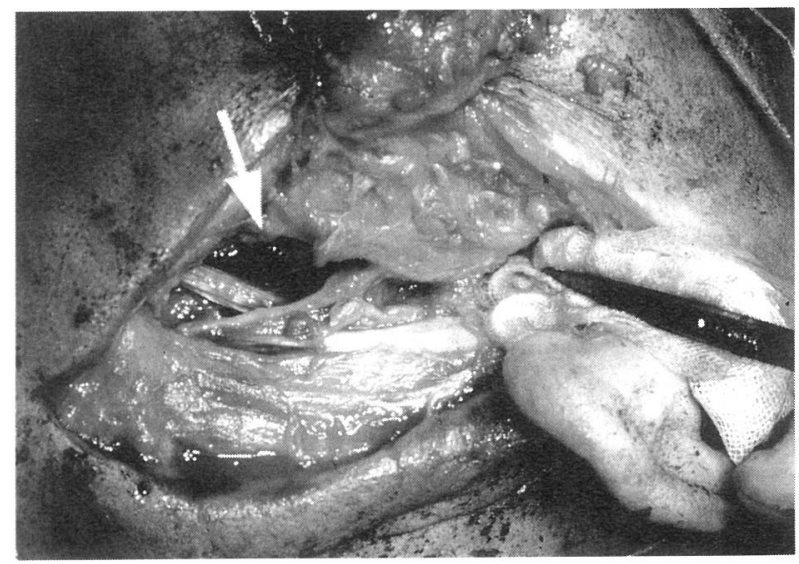

図 8 手術所見(症例 2)

耳下腺浅葉は症痕化していた．数力所を術中迅速生検し たが炎症所見のみで腫瘍性の変化はなかった。耳下腺浅 葉を全摘した。顔面神経との癒着は強くなかった。矢印 が膿瘍腔。

\section{考按}

耳下腺の腫脹を示す疾患では，悪性腫瘍との鑑別が重 要であり，種々の検査が行われる，腫瘍においてはとの 良性, 悪性の鑑別で決め手之なる所見も, 炎症性疾患で は当てはまらないことがある。急性期の耳下腺炎ではそ の鑑別は比較的容易であるが，慢性化したものや膿瘍形 成したものでは，悪性腫瘍と同一所見を示すこともある。 今回の 2 症例では, 耳下腺炎の既往はなく発症も急性で あったが, 手術, 組織所見では疰痕化が強く慢性経過を とったものと考光られる。症例 1 は, 耳下腺の腫脹が急 激であったが疼痛がなく, その他炎症所見もなかったた め耳下腺炎や唾石等に伴う貯留囊胞が考光難かった。 ま た当初腫瘤は硬く, Tcシンチで欠損像, Ga シンチで 陽性像となり, 手術, 組織所見により確定診断を得るま で腫瘍，特に悪性腫瘍を除外し得なかった。 Tcシンチ， $\mathrm{Ga}$ シンチの結果は恐らく膿瘍によるものだと考光られ た、Gaシンチで陽性像は悪性腫瘍だけでなく炎症でも 得られるため注意を要するが1〜3), 症例 1 では炎症の既 往がなく，身体所見，検査所見でも炎症所見はなかった。 針生検に関しては, この時期当科では積極的には行って はいなかったが，行って执くべきであったと考光る。し かし行い，貯留液を吸引できたとしてもそれで悪性疾患 を除外してしまうことに関しては疑問が残る。耳下腺造 影にて円形の腔が証明されたが，炎症性疾患の診断を下 すに至らなかった。炎症もしくは囊胞の可能性を考皇な がらも，悪性疾患を除外できなかったため，確定診断を 兼ね手術を選択した。手術所見では腫瘍は存在しなかっ たが，膿瘍に対して切開排膿4)が行われて扣り，本例で も切開し，ドレナージを行った。腫瘤の増大が急激であ り，炎症所見がそしく，Ga シンチが陽性であったこと が悪性腫瘍を印象づけたと考光る。症例 2 では経過は炎 症が疑われるものの, 硬結の存在と顔面神経麻瘏が, 悪 性腫瘍の存在を印象づた。顔面神経麻痺は耳下腺悪性 腫瘍の診断にとって非常に有力な所見のひとつであり, 腫瘍性病変で顔面神経麻㾝があれば悪性腫瘍と考光るべ きと考兄られている144)5)。しかし急性耳下腺炎6) 8) や糖 疛病9－12）で顔面神経麻痺を合併したといら報告もある. これらの報告にある症例の顔面神経麻㽻が耳下腺炎や糖 㽷病の続発症であるのか，偶発的に同時期に起こったも のであるのかは判断できないが，やはり注意を要する. また，良性腫瘍で顔面神経麻痺をきたしたといら報告も あり 12) 15)，耳下腺疾患に和いて顔面神経麻疾走耳下腺 
悪性腫瘍と直結させることは必ずしも正しいとは言えな いが，顔面神経麻瘏の症状がある以上悪性腫瘍の存在を 念頭に招いて診断, 治療を進めるべきと考光, 確定診断 を兼ね手術を選択した。

以上のように慢性化し膿瘍形成した耳下腺炎では, 悪 性腫場との鑑別が問題となることがあり, 最終診断は手 術所見および病理組織診断によらなければならないこと もある。

\section{まとめ}

1 ）悪性腫瘍との鑑別が困難であった耳下腺膿瘍を 2 例経験した.

2 ）症例 1 では炎症所見がなく, Ga シンチにて陽性 像を示したことが, 症例 2 では顔面神経麻痺の存在が悪 性腫瘍との鑑別を困難にした.

3 ）炎症性疾患を疑いつつも，悪性疾患を除外し得ず， 今回確定診断を得るために手術を必要とした.

本論文の要旨は, 第 54 回耳鼻咽喉科臨床学会総会 (高梘市)に て発表した.

\section{参考文献}

1) 村上 泰: 耳下腺腫瘍の術前診断. 耳下腺腫瘍の臨床(奥 田 稔編). 89 124頁, 医学教育出版社, 東京, 1984.

2 ）原口茂徳：耳下腺腫瘍 RI シンチグラフィーの診断的意義 に関する研究. 日耳鼻 $88: 520 \sim 534,1985$.

3 ）金子敏郎, 林崎勝武：喠液腺悪性腫瘍. JOHNS 2：403 408, 1986.

4) 戸川 清 : 唾夜腺と顔面神経. 耳喉 43:827〜835, 1971.

5 ）北村 武, 金子敏郎, 戸川 清, 他 : 耳下腺腫瘍の臨床
一教室 20 年間の統計的観察一.耳鼻臨床 $64: 1286 \sim 1301$, 1971.

6 ) Robertson JFR and Azmy AAF : Facial paralysis in acute parotitis. Z Kiderchir 42 : 312, 1987.

7 ) Shone GR and Stewart S : Facial paralysis in parotitis. $\mathrm{Br}$ J Surg 72 : 902, 1985.

8 ) Andrews JC, Abemayor E, Alessi DM, et al : Parotitis and facial nerve dysfunction. Arch Otolaryngol Head Neck Surg $115: 240 \sim 242,1989$.

9 ）長江大介, 田中 晃, 谷垣内由之, 他: 当科に扣ける末梢 顔面神経麻痺の統計的観察. 耳鼻臨床 補70：16～21, 1994.

10）高野靖子, 岩沢かをり, 松本 博, 他: 糖尿病性単一脳神 経麻痺を繰り返したインスリン非依存性糖尿病の 4 症例. Diabets Journal $19: 57 \sim 60,1991$.

11）藤野有弘, 浜村亮次 : 糖尿病に合併した両側交代性顔面神 経麻痺. 耳鼻臨床 $81: 663 \sim 669,1988$.

12）笠野藤彦, 安達裕一郎, 黒木幹子, 他 : 顔面神経麻痺を伴 った耳下腺 Pleomorphic Adenoma の 2 症例. 耳鼻 30 : 1073 1077, 1984.

13) DeLozier HL, Spinella MJ and Johnson GD : Facial nerve paralysis with benign parotid masses. Ann Otol Rhinol Laryngol 98 : 644 647, 1989.

14) Papangelou L, Alkalai $K$ and Kyrillopoulou $M$ : Facial nerve paralysis in the presence of benign parotid tumor. Arch Otolaryngol $108:$ 458 459, 1982.

15) Whillis D, Goepel JR and Shorthouse AJ : Facial paralysis due to a benign parotid tumor. Br J Surg $76: 95,1989$.

$$
\left(\begin{array}{l}
\text { 原稿受付 : 平成 } 7 \text { 年 } 10 \text { 月 } 31 \text { 日 } \\
\text { 原稿採択 : 平成 } 8 \text { 年 } 1 \text { 月 } 26 \text { 日 } \\
\text { 別刷請求先 : 田中和成 } \\
\text { 厂5 } 525 \text { 草津市上笠4-2- }-31 \\
\text { 草津中央病院耳鼻咽喉科 }
\end{array}\right)
$$

